\title{
The Economics of Debt Clearing Mechanisms
}

Lars Börner

John William Hatfield

School of Business \& Economics

Discussion Paper

Economics

$2010 / 27$

978-3-941240-39-1 


\title{
The Economics of Debt Clearing Mechanisms
}

\author{
Lars Boerner \\ Department of Economics \\ Free University Berlin \\ lars.boerner@fu-berlin.de
}

\author{
John William Hatfield \\ Graduate School of Business \\ Stanford University \\ hatfield@stanford.edu
}

September 29, 2010*

\begin{abstract}
We examine the evolution of decentralized clearinghouse mechanisms from the $13^{\text {th }}$ to the $18^{\text {th }}$ century; in particular, we explore the clearing of non- or limitedtradable debts like bills of exchange. We construct a theoretical model of these clearinghouse mechanisms, similar to the models in the theoretical matching literature, and show that specific decentralized multilateral clearing algorithms known as rescontre, skontrieren or virement des parties used by merchants were efficient in specific historical contexts. We can explain both the evolutionary self-organizing emergence of late medieval and early modern fairs, and its robustness during the $17^{\text {th }}$ and $18^{\text {th }}$ century.

JEL classification: C78; D02; N23

Keywords: market design; matching; history of decentralized clearinghouses
\end{abstract}

${ }^{*}$ The authors thank Christiaan Bochove, Oscar Gelderblom, Martin Hellwig, Joost Jonker, Scott Duke Kominers, Larry Neal, Muriel Niederle, Albrecht Ritschl, Battista Severgnini, Ken Snowden, Francois Velde, and Daniel Velinov for encouraging discussions and comments. We have benefited from comments of participants at presentations at FU-Berlin, the MPI Bonn, University of Muenster, Stanford University, Cliometrics Conference 2010, the European Historical Economics Society Conference 2009, the European Economic Association meeting 2010, and the Annual Economic History Association Meeting 2010. 


\section{Introduction}

Late medieval Europe was characterized by a revival of trade among the regions of the continent and the emergence of complementary trade-related innovations, a time commonly characterized as the Commercial Revolution (Lopez 1976). Merchants travelled with their goods from one city to the next and many fair locations emerged where traders from different parts of Europe met (Verlinden 1971; Blockmans 1996). An important step in the evolution of trade was the separation of the quid and quo (Greif 2002, 2006). This means that the payment for purchased goods no longer took place at the same time and place but at the next fair or market, either at the same or at a different location. Alongside this development appeared financial instruments like the cambium, letter obligatory, or the bill of exchange, which were orders or promises of future payment at a specific time and place, typically during the payment days at the end of a fair, by the drawer or his representative or banker (Goldschmidt 1891; Schapps 1892; de Roover 1953). This was very useful for a merchant, since he could negotiate a time and place when and where he expected to be liquid again, for example after the successful trading of goods or when he expected to cash in bills himself. Cashless payment was a good alternative to carrying heavy gold or silver coins along dangerous trading routes. In addition, it limited the dependency of merchants on the currency policies of local dukes. Finally, the use of cashless payment helped to overcome the money shortage during the Later Middle Ages due to the scarcity of silver and gold bullion (Miskimin 1984; Spufford 1988). The only downside was the limited tradability of the financial instruments (Usher 1943; Van der Wee 1963; North 1981; Munro 1994; for a discussion see Boerner and Ritschl 2006, 2009).

As a consequence of this development, a need for the settlement of liabilities, typically at the end of a fair or market period, arose. Merchants and merchant bankers met to settle bills of exchange and other liabilities to balance their positions. At fairs and mar-

ket locations, permanent payment days were established over time and, during the $16^{\text {th }}$ century, exclusive clearing fairs in Besancon and later Piacenza and Novi were estab- 
lished where mainly bills of exchange were settled from all over Europe (Endemann 1885; Neuhaus 1892; Ehrenberg 1896; Vigne 1903; Haristoy 1906; Prausnitz 1928; Carande 1943; Lapeyre 1955; Da Silva 1969; Gascon 1971; Boyer-Xambeu et. al.1986; Denzel 1994, 2009). At these late medieval and early modern markets and fairs a specific decentralized multilateral clearing algorithm to offset non-tradable credits with debts was developed. This netting procedure is known in the sources as rescontrire, rescontre, skontrieren, or vivre compte / des parties.

In a nutshell, the procedure worked as follows: all merchants met on fixed days at the end of the market or fair, everybody revealed his debtors, and creditors had to confirm their liabilities. Then, merchants tried to offset credits with debts through a decentralized searching and matching procedure: in the first step, they cancelled reciprocal debts, in the second step, they used clearing cycles, and, in the third and final step, they using clearing chains. At the end, still unbalanced positions had to be paid in cash or new bills had to be drawn.

This clearing mechanism developed at late medieval fairs and was perfected at the financial fairs of the late $16^{\text {th }}$ and early $17^{\text {th }}$ century, where it developed into a formal procedure embedded in a legal framework. This was the dominant debt-clearing mechanism in Europe's most important trade centres: Germany, Italy, France, the Low Countries, and Spain. These markets and fairs not only built the central nodes of European finance and trade but also acquired capital to finance trade with the New World. (Ehrenberg 1896, Da Silva 1969, Boyer-Xambeu et. al.1986; van der Wee 1993, Pezzolo and Tattaro 2008, Denzel 2009).

It waned in importance when the first exchange banks took over the clearing business and general endorsement of bills of exchange during the $17^{\text {th }}$ century (Schneider 1989; Brübach 1994). Nevertheless, there is strong evidence that this decentralized procedure was still in use at many markets and fairs during the $17^{\text {th }}$ and $18^{\text {th }}$ century. In addition, traders who worked under the first stock exchange markets used the same technique to offset payments for stocks or future contracts in cities like Amsterdam and London (Parker 
1974; Gelderbloom and Jonker 2005). After the establishment of the London Clearing Club in 1775, banks began settling their liabilities in a similar way (Seyd 1872). Thus this decentralized multilateral clearing algorithm was the backbone of financial clearing during more than 500 years of pre-industrial growth in Europe.

The research questions of interest are 1) why such clearing mechanisms came into existence and 2) why they were so successful for several hundred years. Of course, these clearing mechanisms reduced the need for cash. However, these mechanisms had to have achieved a high clearing rate. On the one hand, merchant books and contemporary witnesses document that the mechanism was quite successful. On the other hand, legal documents give evidence that merchants were more or less forced to participate in these mechanisms and were not allowed to pay in cash. In addition, there is evidence that merchants had preferences over the choice of their clearing partners and the clearing order.

Not much attention has been paid to the microstructure of this clearing mechanism so far. Legal and economic historians focused on the description, not on institutional analysis. These authors did not come to a clear conclusion about the clearing efficiency. While they recognised the use of the clearing technology for cashless payment all over Europe to generate credit and solve problems of money shortage (Neuhaus 1892; Ehrenberg 1896; Boyer-Xambieu 1986; Brübach 1986; M. North. 1996; Denzel 2005, 2009), a valuation of the clearing mechanism has been missing or efficiency has been assumed simply because of the success of the mechanism. Alternatively, it has been argued that the mechanism was inefficient because the clearing was decentralized and looked rather complicated.

In contrast to these approaches we use a theory-guided approach (Greif 1993, 2006, Greif et al. 1994) to study the efficiency of the settlement mechanism. We analyze the main characteristics of the clearing procedure and develop a theoretical model of the mechanism and proceed to analyze its properties. We examine the matching and clearing of nontradable assets which are complementary in utility to each other when matched efficiently. This modelling goes back to allocation methods using the successive removal of cycles, 
which were first proposed by Shapley and Scarf (1974) for the housing allocation problem and subsequently studied by researchers such as Abdulkadiroğlu and Sönmez (2002), and Ehlers (2002). Recently, Alvin Roth et al. (2004; 2005) applied these techniques to the kidney exchange problem.

We show that the functioning of these mechanisms depends on the balance of positions (credits and debts) of merchants ex ante and the use of clearing cycles or clearing chains. If positions are balanced, then efficient clearing is always achievable with clearing cycles and also with clearing chains. If positions are unbalanced, and only cycles are used, then depending on the ordering of the cycles different levels of clearing efficiencies can be achieved, and some agents may have both credits and debts at the end. However, if chains are used, each merchant will be reduced to his net position. However, depending on the clearing order, the distribution of debt transfers among merchants differs ex post. These properties can lead to strategic behavior of merchants in the form of strategic misrepresentation of information and an unwillingness to participate in specific cycles or chains. This can reduce the efficiency of the clearing.

Consequently, the clearing efficiency depends on the willingness of the merchants to participate in the clearing mechanism in general and the willingness to participate in specific cycles or chains in particular, and these both depend on the expected balance of the positions and the enforcement of unbalanced positions ex post. This enforcement can be achieved through reputation effects or through legal enforcement. Finally, in unbalanced positions, the liquidity of the market after the mutual clearing has been done is important; the ability to draw new bills on future clearing locations increases the willingness to participate ex ante although the merchants expect that positions will be unbalanced ex post. Thus, if merchants are willing to participate in the mechanism all gross positions can be cleared to the net positions by a decentralized search and matching mechanism independent of the ordering of the use of bilateral clearing, cycles, or chains.

These results can explain the self-organizing emergence of this mechanism during the 
late Middle Ages in fairs and financial markets and why during the early modern period a specific form of this mechanism embedded in a legal framework evolved all over Europe. In addition, it can be shown why the mechanism was generally robust and only vulnerable in cases of strong economic shocks or of political abuse. This made it difficult for competing institutions such as the public exchange banks to take over the clearing business.

The remainder of the paper is structured the following way: Section 2 examines the history of the mechanism, from its early development in the late Middle Ages to its perfection in the $16^{\text {th }}$ and $17^{\text {th }}$ century. In addition, the role of exchange banks, endorsement of bills of exchange, the emergence of the mechanism on the first stock exchanges, and the use of the mechanism in the form of clearing clubs among banks are discussed. Section 3 studies the mechanism more formally. A theoretical game model is set up which analyzes the algorithm; the equilibrium outcomes are discussed. In Section 4 the theoretical predicted outcomes are discussed in their historical context. Both the successes and the vulnerabilities of the mechanism are elaborated in detail. Section 5 concludes. The proofs of propositions in Section 3 may be found in the Appendix.

\section{Historical Development}

Section 2 gives a comprehensive historical analysis of the mechanism: Section 2.1 describes the early development until the $16^{\text {th }}$ century, and the formation of the formal procedure and legislation during the $16^{\text {th }}$ and early $17^{\text {th }}$ century, Section 2.2 describes the rules and customary practices, Section 2.3 details the further development, and finally Section 2.4 provides an evaluation of the efficiency based on descriptive source analysis.

\subsection{Early Development and the Formation of a Formal Procedure}

The evidence of the use debt clearing mechanisms such as rescontrire or rescontre can be traced to the late Middle Ages. The first documents do not inform us about a detailed structure or procedure of the clearing process, but just indicate its existence and probably 
its common use. The earliest sources are from Champagne fairs by the end of the $12^{\text {th }}$ and beginning of the $13^{\text {th }}$ century (Anschütz 1887, pp. 108f.; Haristoy 1906, pp. 28488; Face 1957). The use of mutual settlement at the central fair locations of Europe can be again documented from the late $14^{\text {th }}$ century and $15^{\text {th }}$ century onwards: in Germany at Frankfurt, Brunswick, and later Leipzig (Orth 1765, p. 446, Wolf 1967, p. 205f., Bücher 1915, p. 212f. Brübach 1994, p. 284, 307), in France at Lyon (Ehrenberg 1886, pp. 748; Vinge 1903, pp. 110ff.; Haristoy 1906, pp. 296-301; Bresard 1914, Gascon 1971, pp. 242-8; Boyer-Xambeu 1986, pp. 189-198), in the Netherlands at Antwerp and Bergen op Zoom (Ehrenberg 1896, pp. 10-13; van der Wee 1993, pp.151-158), and in Spain at the Castilian fairs of Medina del Campo (Rodriguez and Fernandez 1903, pp. 642f.; Carande 1943, pp. 195-234.; Martin 1965, pp. LXXXII-CIII; Vasquez de Prada 1991, pp. 117f). Early evidence from the $15^{\text {th }}$ and $16^{\text {th }}$ century can also be found in Mediterranean merchant cities with permanent wholesaler markets and finance locations such as Barcelona, Genoa, Naples, and Venice. (Capmany 1792, p. 167; Lattes 1869, pp 72; Ajello 1884, pp. 728ff.; Prausnitz 1928, p. 11)

The common use of this clearing technology in many merchant cities and fair locations during the $15^{\text {th }}$ and $16^{\text {th }}$ centuries was documented by the first regulations which describe the clearing procedure in more detail by the end of the $16^{\text {th }}$ century at the clearing fairs of Piacenza. These regulations from 1597 were taken from the former clearing fairs of Besancon and are called the orders of Besancon. This was the first exclusive clearing fair and was founded by the Genoese in 1537 to compete with and replace the clearing fairs of Lyon, which in turn go back to the second half of the $15^{\text {th }}$ century. Because of this it has been argued that the clearing procedure described in the statutes of Besancon goes back to the customary practice applied by merchant bankers in Lyon. ${ }^{1}$ These orders from Besancon have been recorded by Raphael Turri in 1642, who describes the clearing process in detail

\footnotetext{
${ }^{1}$ This argument goes back to Endemann 1886, p. 174. Customary practices of the 16th century Lyon fair have been handed over by Fabiano 1556, Trenchant 1556, de Savonne 1567; de Rubys 1604. Later authors are Boyer 1627 and Clerac 1656. See Vigne 1903, pp. 118-128; Haristoy 1906, pp. 296-301; Bresard 1914; Gascon 1971, pp. 242-8.
} 
by himself. In addition, Peri 1638 and Sacchia 1645 also give descriptions of the clearing process (Neuhaus 1892; Endemann 1885 174ff.; Ehrenberg 1896, pp. 230-6; Prausnitz 1928; Da Silva 1969, chapter 2).

The regulations can be seen as a blueprint of the procedures that can be found in many exchange laws during the $17^{\text {th }}$ and $18^{\text {th }}$ century in Europe. Similar procedures can be found in the fairs in Italy such as Novi, Bozen and Verona, which replaced Piacenza (Da Silva 1969; Denzel 2005, 2009). In France, Lyon kept on as the clearing centre for bills and other obligations, where the procedures were codified in detail in 1667 based on earlier attempts starting in 1642 (Haristoy 1906, pp. 303ff; Vigne 1903, pp. 118ff.). During the same time, Frankfurt, the most important fair location and finance centre in Germany, produced its first more detailed exchange law. This was inspired by the codification in Lyon. Whereas Frankfurt had already a long tradition of using this clearing technique which goes back to the late $14^{\text {th }}$ century, clearing regulations could only be found in 1578,1611 , and finally a more detailed version in 1666. (Brübach 1994, pp. 169-76). Other important clearing locations with regulations about the mechanism were Bruinswick 1686, 1715 and Leipzig 1682, 1711. ${ }^{2}$ Further evidence is available from merchant cities such as Augsburg, Breslau, Nuremberg and others (Brübach 1994, p. 318; Neuhaus 1892, p. 11). ${ }^{3}$

\subsection{Regulations and Customary Practices}

Clearing took place about four times a year. This goes back to the tradition that fairs were held quarterly and at the end of each fair, a financial clearing was set. ${ }^{4}$ This pattern can be documented for Lyon, the Brabant fairs with Antwerp and Bergen, the Castilian fairs and all the Italian and most of the German fairs (Ehrenberg 1892, Da Silva 1969; van der Wee; Boyer-Xambeu et al. 1986). In cities in which fairs became permanent

\footnotetext{
${ }^{2}$ Very short regulations for Leipzig existed in 1621 and 1676. See Hasse 1886, pp 277f.; Neuhaus 1892 , p. 11; Brübach 1994, pp. $310 \mathrm{ff}$.

${ }^{3}$ Beside the exchange law, contemporary writers like Raumburger (1723) and Riccius (1783) draw on more evidence of the procedure in these places.

${ }^{4}$ For the typical fair's customs, see Verlinden 1971.
} 
markets or when financial clearing was separated from goods trading, the frequency was increased to monthly or even weekly meetings during the $17^{\text {th }}$ and $18^{\text {th }}$ century. This can be documented in the regulations of Frankfurt 1776 and Leipzig 1688, or in Augsburg where only a financial exchange was implemented (Neuhaus 1892, p. 11; Prausnitz 1928, p. 22; Brübach 1994, p. 175, 318). ${ }^{5}$ These clearing meetings lasted several days. In Besancon for example it took eight days, always in a fixed ordering.

In most regulations there were no restrictions on participation. The clearing was open to everybody, however de Turri reports that in Besancon participants were merchant bankers and only they had the right to participate (Endemann 1889; p. 174, Prausnitz 1928, p. 17). Scaccia and Peri write that whoever wanted to participate had to pay a deposit (Endemann 1889, p. 174; Neuhaus 1892, p. 13; Ehrenberg 1896, p. 231). Sometimes merchants attending a fair were forced to take part in the clearing procedure. This was stipulated in the regulations of Bozen and Leipzig (Neuhaus 1892, p. 31, 39). ${ }^{6}$ These rules excluded cash payments or agreements about later payments ex ante by merchants who had not taken part in the mutual clearing procedure. Under the rules of Besancon, merchants who wanted to be paid in cash had to announce this at the beginning and had to seal the money (Ehrenberg 1892, p. 235; Prausnitz 1928; Neuhaus 1892). However de Turri, Scaccia, and Azorius, another writer from 1625, report that merchants had preferences for mutual clearing and were worried about receiving their payments in cash (Neuhaus 1892, p.19, 21; Endemann 1889, p. 179).

The clearing procedure worked the following way: merchant bankers met with their ledgers (scartefacci). In early Besancon there were at least 50-60 bankers. In Piacenza there were about 110 (Ehrenberg 1892, p. 229). Merchants who wanted to participate had to be present or have an official representative. This can be found in the statutes of Besancon and most of the later regulations during the $17^{\text {th }}$ and $18^{\text {th }}$ century (Endemann

\footnotetext{
${ }^{5}$ Permanent marketplaces document weekly meetings earlier on; for example, sources from Naples indicate weekly meetings as early as the 16th century: See Ajello 1884, pp. 728ff.

${ }^{6}$ See also the report by Raumburger (1723).
} 
1885, p. 175 Brübach 1994, pp. 306f.; Neuhaus 1892, p. 30; Haristoy 1906, p. 304f).

Once the set of participants had been determined, all creditors revealed their debtors. ${ }^{7}$ The debtors had to confirm or reject the debts. ${ }^{8}$ In the next step, each banker had to create a balance sheet with all the accepted claims, which had to be submitted in Besancon where officials would check the general balance. ${ }^{9}$ This practice cannot be documented for other fairs later on. Only accepted bills were taken in and were valid for the later mutual netting procedure. Rejected bills were discussed in front of the fair court and settled later. ${ }^{10}$ This regulation was also in use in all other fairs (Endemann 1885, p. 175ff; Prausnitz 1928, p. 17; Brübach 1994, p. 309). De Turri writes that not all bankers were honest and hence were willing to go in front of the court in order to settle some bills later (Endemann 1885, p. 177).

In the next step the exchange rates for the bills were fixed in an official accounting currency. This was done by a group of bankers from different regions who had participated in the clearing process. On the Genoese fairs they came only from different regions in Italy (Endemann 1885, p. 179f.; Ehrenberg 1896, p. 232), in Lyon from France, Germany and Italy (Gascon 1971, pp. 244f.). ${ }^{11}$ The regulations of Besancon state that exchange rates should be reasonable. However, based on these rates, other market prices were negotiated ex post (Ehrenberg 1896, p. 234f.). Having participants from different regions set exchange rates collectively was also typical for later regulations. In Frankfurt, where the fixing of the exchange rate can be documented from 1585 onwards, in 1625 legislation was passed after some bankers at previous fair meetings tried to manipulate exchange rates in their favor; it was stated that the exchange rates were to be decided by local exchange brokers

\footnotetext{
${ }^{7}$ It is not clear if this was all public or happened in a bilateral way: see Ehrenberg 1896, p. 234; Martens 1794, p. 16 Neuhaus 1892, p. 8; Prausnitz 1928, p. 17; Endemann 1886, p. 176; Brübach 1994, p. 175.

${ }^{8}$ See the reports by Scaccia and de Turri, see Endemann 1886, p. 176. For the same practice already in use in Lyon eralier on see Gascon 1971, pp. 243f. and later on see Haristoy 1906, p. 304, in Frankfurt, Brunswick and Leipzig fairs. See Brübach 1994, p. 310.

${ }^{9}$ This was reported by de Turri, Peri, and Scaccia. See Endemann 1886, p. 177, Ehrenberg 1896, p. 234.

${ }^{10}$ The rejection of bills can already be documented for fairs of Lyon during the second half of the $15^{\text {th }}$ century. See Haristoy 1906 pp. 297f.

${ }^{11}$ De Rubys 1604 reports this procedure already for the Lyon fairs during the 16th century. See Vigne 1903, p. 121.
} 
and merchant bankers from different regions (Ehrenberg 1896, pp. 246f. Brübach 1994, p. 287, 311ff.).

In the next step, merchants started the actual clearing process, sometimes with the help of brokers. ${ }^{12}$ This process was organized as a decentralized searching and matching procedure. The codified legal rules in various cities are rather cryptic in describing the process. 13 However, contemporary witnesses give a very lively picture of merchant bankers who were in search of finding clearing partners during the clearing time. ${ }^{14}$ Only in Lyon during the $15^{\text {th }}$ and $16^{\text {th }}$ century was the clearing done by two representatives of the official authorities (Ehrenberg 1896, p. 76). The decentralized clearing algorithm worked the following way. First merchant bankers offset their positions in a reciprocal way. So if merchant banker A owed B and B at the same time owed A, the common amount could be directly cancelled out. ${ }^{15}$ In the next step merchants tried to find clearing cycles and clearing chains. In a clearing cycle, for example, $\mathrm{A}$ owed $\mathrm{B}, \mathrm{B}$ owed $\mathrm{C}$, and $\mathrm{C}$ owed $\mathrm{A}$ a certain amount of money. The common amount then could also be cancelled. ${ }^{16}$ In contrast, in a clearing chain, where A owed B and B owed C, only B could clear his debts and the amount that could be cancelled out had to be transferred into a new debt relationship between A and C. These clearing mechanisms could easily include seven or eight parties (Koenigk 1727, p. 66; Orth 1765 , p. 481; p. E.B.A. 1773, p. 109f.). This clearing process was repeated again and again. For example $\mathrm{C}$ could use the transferred debt in the chain and bring it into another clearing chain or cycle. The sequential clearing can be documented in the ledger by Masse in 1611 (Brübach 1994, pp. 305f.). The clearing process lasted until the clearing

\footnotetext{
${ }^{12}$ The help of brokers can be documented for the German fairs in Frankfurt, Brunswick and Leipzig. See Brübach 1994, p. 316 f.

${ }^{13}$ For example see the regulations of Frankfurt 1611; Brunswick 1686, 1715; Leipzig 1688, Breslau 1742; see Prausnitz 1928, p. 23; Brübach 1994, p. 170.

${ }^{14}$ Evidence can be found in de Turri and Scaccia for the earlier period. For the late $17^{\text {th }}$ and $18^{\text {th }}$ century see Raumburger, Marberger, Riccius, Zipffel. On this see Endemann 1886, p. 178; Prausnitz 1928, pp.17, 23; Neuhaus 1892, p. 9.

${ }^{15}$ Scaccia and de Turri report this for the Genuose fairs. See Neuhaus 1892, p. 8, Prausnitz 1928, p. 17, Endemann 1882, p. 177)

${ }^{16}$ For the Genovese fairs Peri gives an example. See Ehrenberg 1896, pp. 235f. For later fairs see, for example, descriptions by Koenigk and Riccius. See Prausnitz 1928 p. 23; Neuhaus 1892, p. 35.
} 
time came to an end or no merchant could find another clearing partner since everybody had reached his net position. In the exchange regulations, differentiated rules arose about the constraints on participation in the clearing mechanism. In general, the rules gave the merchants the freedom to choose the clearing cycle or chains in which they wanted to participate. de Turri mentions this as an early practice. In addition, we can find the clause that everybody needs to agree to the specific clearing group in most of the exchange laws from the $17^{\text {th }}$ century. ${ }^{17}$ All these sources imply preferences of merchants over participation in different clearing cycles or chains. A writer of a merchant handbook in 1773 reports on the rationale behind this. The author writes "you need to be careful not replacing a good debtor with a bad debtor" (E.B.A. 1773, p. 112). Another regulation that indicates different preferences over the order of clearing procedures is legislation from Frankfurt in 1666 where bankers can first offset their liabilities before those of the customers that they represent (Brübach 1994, p. 176).

After the mutual netting was finished, merchants had to check if they still had outstanding credits or debts. All mutual settlements had to have been written in their scartefacci and having all participants do this made the clearing official. ${ }^{18}$ In general all transfers made by the mechanism were final. This meant if a debtor was transferred to a new creditor, the old creditor was no longer liable. ${ }^{19}$ Only in Besancon was it customary practice that everybody within a clearing chain or cycle was collectively liable. ${ }^{20}$ Legislation ensured that the payment of debts through the clearing mechanism had the same legal status as paying cash. ${ }^{21}$ Even when it turned out ex post that one merchant was bankrupt, priority was given

\footnotetext{
${ }^{17}$ See for example the exchange rules from Frankfurt from 1666, Leipziger exchange orders 1688, Prussian exchange orders 1684, the orders of Bozen 1634 , Brunswick 1715, Augsburg 1716 or the descriptions by Raumburger and Marberger, Riccius. See Neuhaus 1892, p. 29; Prausnitz 1928, p. 22.

${ }^{18} \mathrm{de}$ Turri mentions this regulation and for later fairs also Koenigk, Raumberger, Marberger; see Prausnitz 1928, p. 17f. The regulations can be found in the statutes from Lyon 1667, Leipzig 1688, 1715, Breslau, Augsburg, Bozen: see Neuhaus 1892, p. 12, 31, 38; Prausnitz 1928, p. 17f., 23; Brübach 1994, p. 314f.

${ }^{19}$ For example see the clauses from Frankfurt 1666, Leipzig 1688, Breslau, Brunswick 1686, 1715 or reports by Riccius, Marberger, and Koenigk. See Prausnitz 1928, p. 24.

${ }^{20}$ Contemporary witnesses Fabiani and Merenda inform us about that: Ehrenberg 1896, pp. 235f.; Neuhaus 1892 p. 40; Brübach 1994, p. 318.

${ }^{21}$ For example see the exchange orders of Frankfurt 1611, for 1666; Frankfurt 1666, Lyon 1667, Bozen 1634, Brunswick 1686, Leipzig 1688 or the contemporary witnesses Franck and Phoonsen: Neuhaus 1892,
} 
to the debts that were settled by the mechanism. ${ }^{22}$ Factually, this meant that the payment could not be reversed. This way the mechanism was protected from an ex post unravelling of the settled debts.

In the next step the remaining debts would be settled. Controversial bills which had been rejected by the debtors were judged by the local court (Ehrenberg 1896, p. 236). The payment of outstanding debts could be in cash or by drawing new bills with promises on future payments within a fixed period. ${ }^{23}$ In Augsburg 1778 it was forbidden to draw new bills on one's own name; only cash was allowed (Neuhaus, p. 32). Strict regulations were applied in case a debtor did not offset the outstanding debts by the end of the clearing days: Scaccia and de Turri wrote that participants who did not pay were excluded and declared bankrupt (Endemann 1886, p. 178; Neuhaus 1892, p. 9, Prausnitz 1928, p. 19). ${ }^{24}$ Because of this, Scacchia concluded that merchant bankers with positive positions could easily find new debtors for their money (Endemann 1886, p. 175).

By the end of the Besancon fair a general balance was produced by the officials to control the clearing. However such a general balance was not in use on other clearing locations (Endemann 1886 p. 177; Biener 1859 p. 50).

\subsection{Further Development: Exchange Banks, Endorsement, Stock Ex- change and Clearing Clubs}

From the late Middle Ages there were attempts to establish public exchange banks, whose major task was to serve as clearing houses. This goes back to the first efforts in Venice during the $14^{\text {th }}$ and $15^{\text {th }}$ century with the implementation in 1578 of the Rialto Bank and even earlier by the establishment of exchange banks in several towns in Spain; the first

p. 40; Brübach 1994, p. 171, 374.

${ }^{22}$ See the Besancon regulations, the Statuti di Genoa 1589, Lyon 1667, Leipzig 1688, the Frankfurt legislation 1611, 1666: Neuhaus 1892 p. 8, 40; Brübach 1994, p. 171, 309.

${ }^{23}$ See the statutes of Besancon and Frankfurt 1666, and the contemporary witnesses de Turri, Raumburger and Franck: Endemann 1886, p. 178; Neuhaus 1892, p. 8, Biener 1859, p. 47; Prausnitz 1928, p. 18 u. 30; Brübach, p. 175f.

${ }^{24}$ This practice was also already known in Lyon. See Vigne 1904, p. 126; Haristoy 1906, p. 300. Additionally, in the regulations from 1667 strict payment periods were fixed. See Haristoy 1906, pp. $305 f$. 
was in Barcelona in 1401 (Usher 1943; Braudel 1966; Lane and Mueller 1985). The exclusive right was given to most of these banks to handle the exchange business. However from the fragmented data we possess we know that merchants were not interested in using these centralized institutions to balance their positions. After the founding of the bank in Venice, in 1593 a regulation was passed which forbade the use of the rescontre technique; all bills had to be brought to the Bank. This regulation was later rescinded and decentralized clearing was allowed again (Lattes 1869, pp. 170f.). North of the Alps, efforts to install public clearing locations did not start until the beginning of the $17^{\text {th }}$ century. The first bank was the Wisselbank of Amsterdam in 1609 (Van Dillen 1934; van der Wee 1977; de Vries and van der Woude 1997), which was a copy of the bank in Venice. More banks in the Netherlands were established during the $17^{\text {th }}$ century, as well in Germany at Hamburg in 1619 and Nuremberg in 1621 (Sieveking 1934; Fuchs 1954). The success of these institutions was rather mixed. Whereas the Amsterdam exchange bank was a big success as a multifunctional institution, its role as exclusive clearing bank had to be legally enforced again and again. Even when the service was inexpensive or, until 1683, free, merchants were not willing to use the institution (van Dillen 1964, p.398; Sneller 1940, pp. 157-160). When the bank started its activities, private cashiers were forbidden to conduct the clearing business, but by 1621 the decision was reversed. In 1700 merchants were forced up to an amount of 600 and later 300 guilders to use the bank (van Velden 1933). In Hamburg in 1693 they were forced to use the bank for amounts higher than 400 marks. Merchants were not allowed to use the direct clearing procedure (Prausnitz 1928, p. 26). In Nuremberg, bank orders from 1654 and 1721 inform us that merchants were not allowed to use the Skontration to settle their bills, but had to bring them to the exchange bank. In addition, the orders from 1654 indicate that merchants were only willing to hand in the bills which they could not clear easily or that were unbalanced positions (Neuhaus 1992, p. 12; Prausnitz, p. 1928). However, decentralized clearing was again allowed later. In important clearing locations such as Frankfurt or Leipzig no clearing banks were introduced, but merchant 
bankers relied on the decentralized practice in use. A similar story can be told for Lyon, France's main clearing location, where several efforts to install a central bank before the $18^{\text {th }}$ century failed (Velde 2009). One of the main reasons was a lack of trust in the activities of the bank. This can also be documented in the case of the banks of Nuremberg (Fuchs 1954, pp. 55-58).

Another important innovation which influenced the Skontration was the more frequent use of the endorsement of bills during the $16^{\text {th }}$ and $17^{\text {th }}$ century. Tradability of bills goes back to the late Middle Ages and can be documented for the $14^{\text {th }}$ century (Munro 1994; Opitz 1967 , van der Wee 1993). Thus it was quite natural for the decentralized clearing locations to be confronted with transferred bills. The reaction to these bills was different from place to place. In Antwerp, with the growth of economic activities during the early $16^{\text {th }}$ century, the transfer of financial instruments became standard and the court confirmed the use of transferable bills several times during the late $16^{\text {th }}$ and early $17^{\text {th }}$ century (van der Wee 1977, pp. 149-63). In Frankfurt, legislation went a different way (Schneider 1991, Brübach 1994, p. 171-4). The court declared, probably based on requests by fair bankers in 1620 and 1635, that the usage of the endorsed bills was forbidden since it brought abuse, disorder and confusion into the clearing mechanism. Only in 1666 after vehement protests by merchants who were accustomed to the endorsement technique from the financial centers of Europe like Lyon and Antwerp was the judgement annulled. However, a regulation from Lyon 1678 restricted the use of transfered bills from the Italian towns of Venice and Bozen (Haristoy 1906, pp. 309f.). This was probably due to the fact that these exchange places did not allow for endorsement (Schneider 1991, pp152f.). Hence, the town officals from Lyon feared disorder in the clearing mechanism. A similar story of resistance to the endorsement technique as documented in Frankfurt can be reported from Italian fair locations. The reason for this opposition could be seen in the strong lobbying of the wellestablished bankers of these fairs since the use of the endorsed bills reduced the need of the exchange fairs (Prausnitz 1928, p. 21; Neuhaus 1892 p. 11, Schneider 1991, pp. 150-3). 
The reduction of this need due to the endorsement was noted by Raumburger in 1723 (p. 671).

Similar decentralized clearing procedures appeared in the first stock exchange markets. In Amsterdam, traders of stocks and futures started to meet informally during the 1630s, probably once every month to offset their credits and debts in the form of stocks and futures (Geldbloom and Jonker 2005, pp. 204f.). Probably from the 1650s onwards the Amsterdam exchange established fixed clearing days every fourth month to settle mutual obligations. Furthermore, during the $18^{\text {th }}$ century speculators in English funds created their own clearing days, also four times a year. (Wilson 1941, p. 83ff.). Finally, in London, regular clearing days were introduced, probably during the 1740s. However, also in London, traders met informally earlier in coffeehouses to offset their liabilities (Dickson 1967, p. 507ff.).

Another development we find is that national clearing clubs were introduced during the late $18^{\text {th }}$ and $19^{\text {th }}$ centuries between banking houses. It has been documented that some merchants attempted to establish clearing clubs at exchange fairs. In Frankfurt in 1642, 23 merchant bankers decided to meet regularly to clear their liabilities. Similar efforts can already be documented by Italian bankers, who started small clearing fairs during the 1570 s, when the Spanish bankruptcy led to uncertainty among the merchant bankers (Denzel 1994, pp. 316f).

Such agreements can be found by banking houses to clear liabilities in the late $18^{\text {th }}$ century. In London in 1775, several private bankers agreed to build a clearing club, the London Clearinghouse, to settle their liabilities. Before this agreement, bankers had to present checks to each other and to settle individually. Anecdotal evidence suggest that cash messengers from different banks first met informally over breakfast and offset the liabilities so that they only had to cash in the unbalanced positions later on.

The clearing procedure was very similar to the procedure known from the clearing fairs. Each morning during the week the representatives of the banks met and presented the financial obligations. During the day the representatives had time to verify the debts. In 
case the obligations were approved, the representatives offset their credits and debts. The remaining open positions had to be paid in cash (Seyd 1872, pp. 52ff.). The idea of such a clearing club was taken up during the 19th century in Dublin in 1845, in New York in 1853, Paris and Vienna in 1872, and Berlin in 1884 (Koch 1983).

\subsection{Efficiency of the Mechanism: Evidence from Merchant Books and Contemporary Witnesses}

Having outlined the historical evolution of these clearing mechanisms, it remains to be answered whether or not these mechanisms were efficient in the sense that a high clearing rate could be achieved without paying cash or writing new bills if not necessary. The existence of the mechanism across Europe and the preference by merchants to use the mechanism instead of central public exchange banks indicates that this institutional solution must have worked relatively well. In addition, the large numbers of bills cleared this way gives further evidence (Ehrenberg 1896) that these clearing fairs were successful. It seems that only the economic or political abuse of the institution by manipulating exchange rates or delaying payment or bankruptcy of some major merchant bankers or economic crises led to a downturn of these decentralized clearing mechanisms. ${ }^{25}$

Another way to approach this question is to analyze one of the few scartefacci which was handed down. The ledger of the 1632 autumn fair in Frankfurt of the merchant banker Johan Bodeck gives detailed evidence of the clearing process at work (Brübach 1994, pp. 331f.). Bodeck was involved with 77 people during the whole clearing process. This contained reciprocal clearing, cycles, and chains. These merchants and bankers were from all over Europe north of the Alps. Clearing partners came from Aachen, Amsterdam, Augsburg, Breslau, Dresden, Frankfurt, Hamburg, Leipzig, Strasbourg, Ulm and from unknown locations. During the clearing, he transacted the total amount of 135,000 florins, but only 4,000 florins were paid in cash. The rest could be compensated via the clearing procedure.

\footnotetext{
${ }^{25}$ See Vasquez de Prada 1991, pp. 121-125 for the Castilian fairs; Denzel 1994, 311ff. for Lyon and the Italian fairs.
} 
Thus, more than $99.3 \%$ could be cleared by mutual settlement. Taking this single booklet as a sample, the clearing technique was very successful. However, can we generalize this single case study or was this high clearing rate pure chance?

Another approach is to analyze the reports of the contemporary witnesses. Whereas an early witness, the merchant Davanzati in 1560 commenting on Besancon looked with some ridicule at the mechanism (Ehrenberg, p. 229), writers of the $17^{\text {th }}$ and $18^{\text {th }}$ century, such as Sotus, Molina, Azorius, Scaccia, and de Turri admired the clearing process. Scaccia and de Turri write that nothing was rarer than money at these clearing fairs (Endemann 1886, pp. 178f.; Neuhaus 1892, p. 10; Haristoy 1906, p. 300). ${ }^{26}$ Merchant bankers only brought money for their expenses. Only Koenigk, Raumburger, and Marberger (Prausnitz 1928, p. 25) mentioned with the emergence of exchange banks that they were surprised that not more places had a centralized exchange bank since they were better than the decentralized clearing procedure. Based on these reports, the mechanism must have been rather successful.

However if the mechanism was so successful and led to a high clearing rate, why did some of the regulations force merchants to participate and not to pay cash in advance? Why did the statutes mention the freedom of merchants over the order and the clearing partnerships in which they could be involved? If the mechanism worked that well why did merchants have preferences about clearing different clearing chains and cycles? Could the endorsement of the bills of exchange have been so vulnerable for the mechanism in use? We now turn to a theoretical model of the mechanism to answer these questions.

\footnotetext{
${ }^{26}$ De Rubys and Clairac argues in a similar way for the Lyon fairs; see Haristoy 1906, p. 300 Gascon 1971, p. 248.
} 


\section{A Model of Medieval Debt Trading}

\subsection{Setup}

We consider a model with a set $\mathbb{N}=\{1, \ldots, N\}$ of agents. Each agent $i \in \mathbb{N}$ is endowed with a set of debts $d_{i, 1}, d_{i, 2}, \ldots d_{i, N} \geq 0$ where $d_{i, j}$ represents the debt that $i$ owes $j$ (and where $d_{i, i} \equiv 0$ ). We call the complete characterization of a set of debts and credits $\left\{d_{1,1}, d_{1,2}, \ldots, d_{1, N}, d_{2,1}, d_{2,2}, \ldots d_{2, N}, \ldots, d_{N, 1}, d_{N, 2}, \ldots, d_{N, N}\right\} \equiv \mathcal{A}$ an allocation. We will call

$$
\sum_{j=1}^{N}\left(d_{i, j}+d_{j, i}\right)
$$

the trader $i$ 's net position: if $i$ 's net position is 0 , we shall call his position balanced.

We will only consider mechanisms that leave unchanged every trader's net position. Hence, each trader's utility is defined only over the total number of outstanding commitments he has. We define the utility function of trader $i$ as

$$
U_{i}=-\sum_{j=1}^{N} \alpha_{i, j} d_{j, i}
$$

where $\alpha_{i, j}$ is the disutility for agent $i$ of holding a debt from agent $j$. Note that this can vary between agents; some agent $j$ may be a good credit risk for $i$ and have a low $\alpha_{i, j}$, while some other agent $k$ may be a poor credit risk, and hence $\alpha_{i, k}$ will be quite large. We also assume that the utility of the trader is just a total of the disutility of each credit he is holding from other agents.

In this context, a Pareto efficient allocation is any allocation that maximizes a weighted sum of utilities. We also wish to consider the strategic implications of the mechanisms used. At a fair, an announced debt had to be confirmed by the presumptive debtor. Hence, strategic considerations are important: mechanisms that allow manipulation by denying debts (which the debtor can then pay off later) must not improve outcomes for the manipulator: otherwise, the merchants will have an incentive to deny debts during the clearing process, which may ruin the ability of these debt clearing mechanisms to function efficiently. 
Therefore, we will assume that agents have the ability to deny a debt: that is, for any $d_{i, j}>0$, agent $i$ can deny the debt, and the mechanism must proceed as if $d_{i, j}=0$. Formally, the strategy set of the agent $i$ (for a given allocation $\mathcal{A}$ ) will consist of confirming or denying $d_{i, j}$ for any $d_{i, j}>0$. The mechanism will then proceed using the input allocation $\mathcal{A}^{\prime}$, which is the allocation including only confirmed debts.

\subsection{The Case of Balanced Positions}

We first consider the case when each agent $i$ 's financial position is balanced, in the sense that he is neither a net debtor or creditor: that is, for all $i \in \mathbb{N}$, we have that

$$
\sum_{j=1}^{N}\left(d_{i, j}+d_{j, i}\right)=0
$$

Note that in this case the only Pareto optimal allocation is unique, and

$$
\sum_{j=1}^{N} \alpha_{i, j} d_{j, i}^{*}=0
$$

for all $i \in \mathbb{N}$.

In this section we first wish to consider the cycle removal mechanism. For this mechanism, we search for a cycle of agents $i_{1}, i_{2}, \ldots, i_{M}, i_{M+1}=i_{1}$ where $i_{a} \neq i_{b}$ for $a \neq b$, $a, b \in\{1, \ldots, M\}$ and $d_{a, a+1}>0$ for $a=1, \ldots M$. Essentially, we are looking for a cycle of agents, each of whom owes the next agent a positive amount. We then "clear"the

cycle by setting letting $\hat{d}=\min _{a=1, \ldots, M}\left\{d_{i_{a}, i_{a+1}}\right\}$ and subtracting $\hat{d}$ from $d_{i_{a}, i_{a+1}}$ for all $a=1, \ldots, M$. While the cycle removal clearing mechanism obviously applies to the case when only cycles are cleared, it also incorporates the case where merchants were required to pay cash at the fair so that the ending positions were balanced.

Note that we have not defined in what order the cycle removal mechanism removes cycles. However, the exact order of the cycle removal does not concern us, as it does not affect the final outcome:

Proposition 1. If all agents have a balanced position, any cycle removal mechanism will completely clear all debts and hence is efficient. 
The essence of the proof lies in accounting: if some agent $i$ has a debt, then the agent $j$ to whom $i$ owes a debt owes a debt in turn to someone else, as his position is balanced. Since all positions are balanced, this string of logic can be continued until a cycle is found; there are only $N$ agents, so at some point this chain must bend back in on itself.

Since, with balanced positions, all debts are cleared, we have that it is a Nash equilibrium for agents to truthfully reveal all their debts, since if they reveal all of their debts, they will completely clear all of their positions, which maximizes their utility.

Proposition 2. If all agents have a balanced position, it is a Nash equilibrium to reveal all debts.

The easiest way that an agent could misstate his position is by not entering the cycleclearing mechanism at all. However, since the proposition states it is a Nash equilibrium to truthfully reveal all of one's debts, it is a Nash equilibrium for all traders to enter the mechanism, a corollary of the above result is that all agents will wish to enter the mechanism.

Corollary 1. If all agents have a balanced position, it is a Nash equilibrium for all agents to enter the mechanism.

\subsection{Unbalanced positions}

However, if agents do not have balanced positions, the nice properties of cycle removal mechanisms break down. First, a particular cycle removal mechanism will not necessarily be even Pareto efficient, much less efficient in the sense of minimizing the total remaining debts. Consider the example in Figure 1 below, where each arrow denotes the owing of 100 florins: e.g., $A$ owes $E$ and $B$, and is owed by $D$, etc., and suppose that $\alpha_{i, j} \equiv \alpha$ for all $i, j$. Then a cycle removing mechanism may well choose to remove the cycle $A, B, C, D, A$ first, after which no more cycles can be removed. Note that each agent in the removed cycle has one 100 florin open position after the cycle clears, and the two agents not involved, $E$ and $F$, have 200 florins of open positions. Even though their net position is zero, they can 


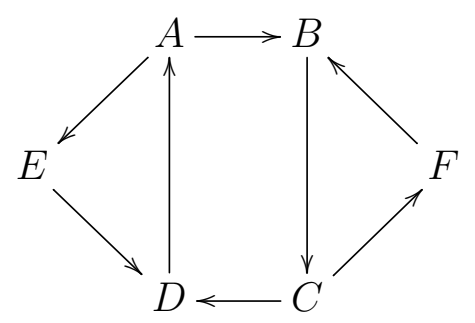

Figure 1: A diagram of a possible allocation. An arrow from $i$ to $j$ represents $d_{i, j}=100$.

not clear their accounts using just cycles, as their creditor is a net creditor and their debtor is a net debtor.

On the other hand, if the cycle $A, E, D, A$ is removed, then the only remaining cycle is $B, C, F, B$; after removing these two cycles, only agents $A, B, C$, and $D$ have open positions of 100 florins. So while the four agents $A, B, C$, and $D$ may be indifferent, both $E$ and $F$ would be better off if the mechanism removed the smaller cycles first. ${ }^{27}$ Hence, as the financial positions of fairgoers becomes more complex, we would expect additions to, or a wholly different mechanism from, the cycle removal mechanism that works well when all positions are balanced.

Hence, we now consider chain removal mechanisms. A chain removal mechanism is, in a certain sense, simpler than a cycle removal mechanism: whenever we find a sequence of agents $i_{1}, i_{2}, i_{3}$ such that $d_{i_{1}, i_{2}}>0$ and $d_{i_{2}, i_{3}}>0$, we call this a chain. For any chain, we let $d=\min \left\{d_{i_{1}, i_{2}}, d_{i_{2}, i_{3}}\right\}$ and subtract $d$ from both. If $i_{1} \neq i_{3}$ we also add $d$ to $d_{i_{1}, i_{3}}$. Hence, since $i_{1}$ 's debt is passed onto $i_{3}$, the net positions of the three agents do not change. For example, if $A$ owes $B 100$ florins, and $B$ owes $C 60$ florins, and $A$ owes $C 20$ florins, then we rearrange the debts so that $A$ owes $B 100-60=40$ florins, and $A$ owes $C$ $20+60=80$ florins, but $B$ no longer owes $C$ any florins. The result of any chain removal is to set either $d_{i_{1}, i_{2}}$ or $d_{i_{2}, i_{3}}$ to zero; of course, it may increase $d_{i_{1}, i_{3}}$ from zero to $d$. Note, however, that it reduces the total open debt by at least $d$, as both $d_{i_{1}, i_{2}}$ and $d_{i_{2}, i_{3}}$ fall by $d$

\footnotetext{
${ }^{27}$ Note that the fact that we wish to remove the smaller cycles first in this example does not generalize. In particular, note that if we replaced $E$ with a chain of several agents, it would be better to remove the larger cycle first.
} 
(and $d_{i_{1}, i_{3}}$ increases by at most $d$ ).

We have not defined the order in which we remove chains. One type of chain removal mechanism is that which removes cycles first, and only afterwards removes chains. The transfer of debts could explain such preferences by merchants. Indeed, the chain removal mechanism can be considered an extension of the cycle removal mechanism. For instance, first using a cycle removal mechanism and then removing the remaining chains (in any order), would still be a chain removal mechanism: we can simply consider removing the cycle as removing the chains in a particular order, as the cycle $i_{1}, i_{2}, \ldots, i_{M}$ can be thought of as consisting of the chains $i_{1}, i_{2}, i_{3}$, then $i_{2}, i_{3}, i_{4}$, etc.

Furthermore, the chain removal mechanism is exactly what is necessary in order to reduce each trader's position to only debts or only credits, even when positions are unbalanced:

Proposition 3. Any chain removal mechanism will result in each trader having only debts or only credits.

The idea of the proof is straightforward: if some agent has both a credit and a debt, we can use these to find a chain.

Note, however, that the chain removal mechanism is not deterministic: if positions are unbalanced, then different allocations can result from the same starting point, depending on the order of the removal of the chains. Consider the case when $A$ and $A^{\prime}$ both owe $B$ 50 florins, who in turn owes $C 50$ florins. Then, depending on the order of chain removal, either $A$ or $A^{\prime}$ will owe $C 50$ florins, while the other will still owes $B 50$ florins.

Hence, when merchants have preferences over their debtors, it is not necessarily the case that removing a chain results in a Pareto superior allocation; removing a particular chain may make one of the traders worse off, as he now has a debtor whom he disprefers. In particular, then, if positions are unbalanced (and cash payments to settle positions are not required) and merchants have strong preferences over their debtors, the mechanism may fail to induce much clearing, as merchants will not allow chains to clear which leave 
them with worse debtors. For instance, $C$ may prefer $A$ as a debtor to $A^{\prime}$, while $B$ prefers $A^{\prime}$ to $A$. Then if we clear the $A^{\prime}, B, C$ chain, the resulting allocation will be Pareto inferior to the allocation where we clear the $A, B, C$ chain.

In particular, it may be the case that an agent may not wish to allow certain cycles to clear, so as to avoid exchanging a debt with one member of the mechanism for another. In Figure 1 above, then, if $B$ does not wish to hold a debt from $C$ or $F$, it is important that he be able to keep the $A, B, C, D, A$ cycle from clearing, as then he can ensure that the $B, C, F$ cycle clears instead. If he did not have this option, then the mechanism would suffer, as then $B$ would have an incentive to deny his debt to $C$, so as to ensure that the cycles he prefers are the ones to clear.

Another motivation for wishing to choose the cycles that clear is that the merchant may have preferences due to the exchange rates that were used for the clearing. It may be that clearing a particular chain would force the merchant to exchange debts at what the merchant perceives is an unfavorable exchange rate. Hence, at fairs where debts of several currencies are exchanged, it is even more important to give merchants the freedom to choose which chains clear in order to ensure willingness to participate in the mechanism.

However, when agents do not have preferences over which debts they hold, the chain removal mechanism has even stronger strategic properties than the cycle removal mechanism: in particular, it is an optimal strategy for all players, regardless of the actions by other players, to truthfully reveal their debts.

Proposition 4. Suppose that $\alpha_{i, j}=\alpha$ for all $i, j \in \mathbb{N}$. Then it is a (weakly) dominant strategy for all agents to truthfully reveal their debts under a chain removal mechanism. Furthermore, the resulting allocation is Pareto optimal.

The key idea here is that the removal of any given chain can only help the individuals involved. When removing a given chain $A, B, C$, the utility of $A$ and $C$ remains the same. However, the utility of $B$ is increased by $\alpha d$, where $d=\min \left\{d_{A, B}, d_{B, C}\right\}$. Hence, all three agents within the chain or at least weakly better off when the chain clears. This 
proposition applies particularly to the case where merchants participate in a clearing club, where the assumption that the disutility from a debt is the same across club members is reasonable to apply.

\section{Discussion of the Results in Historical Context}

We now consider these theoretical results in their economic and historical context. Theory predicts efficient outcomes if participants are willing to get involved in clearing chains and clearing cycles. If this is the case a merchant who participates in the clearing mechanism can clear all his debts and credits up to his net position as long as everyone else participates. Hence, we can rationalize the decentralized search and matching procedure as the decentralized nature of these institutions did not impede their efficiency. Furthermore, a merchant can clear his debts and credits in any order. If the composition of the liabilities of the bills allows several clearing paths, then the clearing order does not matter. Therefore, all we need for the success of the clearing is that the merchants meet at a specific time and work through the various chains and cycles: no centralized authority is necessary. This is what we found as customary practice earlier on and later regulated in the exchange laws. Crucial in this process is that no questionable bills be used since this would destroy the clearing sequence. Thus, the common practice in the legislation to sort out these bills ex ante can be explained. The fear of using endorsed bills can also be interpreted along this line. As long as the legislation and the enforcement of these liabilities were not clear, endorsed bills could bring disorder into the mechanism as judged by the Frankfurt court.

The willingness of a merchant to participate in a clearing cycle or clearing chain ex ante depends on the expectations of balanced positions ex post or in case of expected unbalanced positions on the likelihood that a creditor gets paid in cash or makes a satisfactory deal by drawing on new bills. If either of these conditions is satisfied, he will participate in any clearing cycle or chain. We can understand the strong fair regulations on balancing positions for example in Besancon or Lyon, i.e. paying cash before the end of the fair 
and otherwise being declared bankrupt and excluded from any future clearing processes, since this increases the willingness of the wealthy merchants to participate in the clearing mechanism. However, if a merchant expects unbalanced positions at the end, for example if he learns that many merchant bankers will not be able to balance their debts, he will stick to clearing cycles since this guarantees him direct clearing; even a bankrupt clearing partner ex post will not harm him according to the regulations discussed earlier on. If he selects chains he must be careful not to pick a new partner who, as is written in the merchant booklet, turns out to be a bad debtor. If he prefers using cycles only, he might have preferences over the order of the clearing process, since this can determine the outcome and his personal clearing rate by only using cycles. Consequently, we can rationalize all the regulations we found in the exchange legislations which gave the merchant the freedom to participate in any cycle or chain, and to choose in which ordering he liked to clear, as otherwise a merchant may have incentives to misreport his positions in order to change his eventual set of debtors or not to participate at the clearing mechanism at all. Following this line of argument, we can also understand why merchants sometimes preferred clearing debts in cash, since they preferred receiving cash ex ante from the original debtor to trying to cash in the debts from a new debtor due to the clearing process. At the same time the officials who organized the clearing fair had an interest in keeping in as many debtor-creditor pairs as possible because this created positive externalities for other merchants who participated in the clearing. The discussed regulations from Bozen or Leipzig on forced participation can be rationalized in this way.

In addition, the use of strict regulations that forced participants after the mutual settlement to balance their positions can be explained. In an early stage, when such a mechanism was set up by a small number of merchants, we can expect reputational forces to have kept the mechanism running. However, when the number of participants increased, it was necessary to impose legal sanctions. An alternative to this are clearing clubs, where the number of participants is restricted to merchants who know each other. However, the 
clearing mechanism allows some anonymity. As long as merchants only participate in cycles it does not matter if they need to rely on reputation or legal enforcement ex post since the common amount can be cleared anyway. In addition, in clearing cycles and clearing chains each participant knows at least one partner with whom he had already done business. Finally, in case one participant rejected a certain clearing chain, he still could search for other clearing partners to proceed with the clearing. Achieving a Pareto efficient clearing depends then on the number of theoretical clearing paths available and on the original liability composition and structure of the merchants. More broadly, the observed mechanism is an institutional solution of an economic world in transition from a reputation-based system to a more anonymous trade-based system with limited centralized outside enforcement options (Greif 2002, 2006).

Furthermore, the mechanism is rather robust and we can expect high clearing rates. The question then remains under which circumstances the mechanism becomes vulnerable. The mechanism is robust against small shocks and the bigger the clearing location, the less likely it is that small disturbances will influence the clearing process. However, the mechanism is not robust against heavy shocks as we can observe for example during the second half of the $16^{\text {th }}$ century in Lyon. If too many merchants cannot pay their debts, then participants can not only expect unbalanced positions, but also a shortage of money on the aftermarket, since too few bankers come out of the clearing with positive net positions. Furthermore, we can expect less willingness to give future credit to probably bad creditors.

Observing the empirical success and the theoretical efficiency of the decentralized clearing mechanism explains the limited success of the early public clearing banks. A clearing bank can always replicate the efficient clearing because it works as an intermediary who takes in and hands out the compensation directly. However if we expect efficient or close to efficient clearing using the decentralized clearing procedure, what extra benefits can the central bank offer to the merchants? The public bank can work as an intermediary who enforces unbalanced positions. In contrast to the decentralized clearing house, a 
creditor can always rely on the same partner and does not have to deal each time with new debtors, who are determined by the sequence of the decentralized clearing process. The bank orders of Nuremberg imply such a rationale by their customers. The merchants of Nuremberg were willing to hand in bills which they could not clear easily; for these bills, they preferred to rely on the enforcement of the bank. However, the document also informs us that they handed in only these bills; decentralized clearing for the other bills was still preferred. The enforced participation constraints by other banks also point in this direction. A follow-up question can then be asked: why did merchants prefer not to go to these public banks? We see from sources that document the early phases of these institutions that some exchange banks were chronically short of money. Furthermore, town officials, who governed these banks, were always passing new regulations for these banks (Fuchs 1954, pp. 55-8). Therefore, the unwillingness of merchants to deposit all of their bills into these banks comes as no surprise. During the early $18^{\text {th }}$ century Marberger $(1717, \mathrm{pp}$. 98f.) comments on this problem (Schneider 1991, p. 142). In addition, by using these new public institutions, merchants would have to reveal certain private business information to these banks, and in many cases the merchants probably did not wish to do so (Velde 2009). Finally, at fairs exchange rates were negotiated by representatives of different merchant groups. In the public banks merchants had to rely on the decision makers of the bank. Thus, based on this bargaining argument the participants of the fairs could expect better exchange rates at exchange fairs than in public banks. Consequently the later success of the exchange banks must be explained by a slow evolution of trust in these new centralized institutions and other complementary institutional advantages which go beyond the clearing mechanisms (for example see Quinn 2006, 2007).

\section{Conclusion}

This paper examined the evolution of a decentralized multilateral debt clearing algorithm for non- or limited-tradable debts during the late medieval and early modern period in 
Europe. We constructed a simple theoretical model of the mechanism and showed that the mechanism could lead to very high clearing rates. In this way the common use of the mechanism can be rationalized.

We first examined the history of the mechanism. We analyzed the early emergence of this mechanism on Late Medieval markets and fairs and showed how the clearing algorithm developed into a standardized procedure embedded in a legal framework during the early modern period in use all over Europe. We identified the main elements of the procedure, based on legal sources and writings of contemporary witnesses. We then set up a model which simulates the mechanism and identifies the equilibrium outcomes and related strategic behavior of participants.

We showed that the functioning of the mechanisms depends on the balance of positions of merchants ex ante and the use of clearing cycles or clearing chains. If positions are balanced, then efficient clearing is always achievable with clearing cycles and also with clearing chains. If positions are unbalanced, it is necessary to use not only cycles but also clearing chains. Furthermore, whereas in the case of balanced positions the algorithm is deterministic, in case of unbalanced positions it is not. If cycles are used, depending on in which order the cycles are removed, different levels of clearing efficiencies can be achieved. If chains are used, merchants can always reduce their position to being solely a creditor or debtor, but depending on the clearing order the distribution of debt transfers among merchants differs ex post. These properties can lead to strategic behavior of merchants in the form of strategic misrepresentation of information and non-willingness to participate in specific cycles or chains. This in turn reduces the efficiency of the clearing.

These results can explain the self-organizing emergence of this mechanism during the late Middle Ages in fair and financial markets and why during the early modern period a specific form of the mechanism embedded in a legal framework evolved all over Europe. In addition, it can be shown why the mechanism was in general robust and only vulnerable in cases of strong economic shocks or of political abuse. This made is it difficult for 
competing institutions such as the public exchange banks to take over the clearing business.

These results open up new questions for future research. The results here analyze the microeconomic properties of these clearing mechanisms. However interesting questions related to trade and credit flows on a macroeconomic level could be discussed. It is well known that all these clearing locations were linked and embedded in a common network. Therefore the evolution and robustness of this network related to the microeconomic findings of this paper should be further discussed. In particular, the role of unbalanced trade and credit flows would be of great interest.

\section{References}

Abdulkadiroğlu, Atila and Tayfun Sönmez. 2002. "House Allocation with Existing Tenants." Journal of Economic Theory, 88 (2): 233-260.

Anschütz. 1887. "Das Institut der Zahlwoche auf den französischen Messen im Anfang des XIII. Jahrhunderts.” Zeitschrift für das gesamte Handelsrecht, 17:108-9.

Ajello, Pietro. 1882. "Il depositi, le fedi di credito e le polize dei banchi di Napoli." in: Il Filangieri, 7 (1),:641-665 and 713-755.

Azorius, J. 1625. Institutiones morales. Lyon.

Biener, Friedrich August. 1859. Wechselrechtliche Abhandlungen. Leipzig.

Boerner, Lars, and Albrecht Ritschl. 2006. 'Making Financial Markets: Medieval Communal Responsibility and the Coexistence of Money and Credit in a Monetary Matching Model." Paper presented at the Society of Economic Dynamics Conference, Vancouver.

Boerner, Lars, and Albrecht Ritschl. 2009. "The Economic History of Sovereignty: Communal Responsibility, the Extended Family, and the Firm." Journal of Institutional and Theoretical Economics, 165 (1): 99-112.

Boyer, Claude. 1619. L’artithmétique des marchands. Lyon.

Boyer-Xambeu, Marie-Thérèse, Ghislain Deleplace and Lucien Gillard. 1986. Monnaie Privée et Pouvair des Princes. Paris: Presses de la Fondation Nationale des 
Sciences Politiques.

Blockmans, Wim. 1996. ”Das Westeuropäische Messenetz im 14. und 15. Jahrhundert.” In: Europäische Messen und

Maerktesysteme in Mittelalter und Neuzeit, ed. Peter Johanek and Heinz Stoob, 37-50. Köln: Böhlau Verlag.

Braudel, Fernand. 1976. The Mediterranean and the Mediterranean world in the age of Philip II. London : William Collins.

Brésard, Marc. 1914. Les foires de Lyon au XVe et XVIe siecles. Paris: Picard.

Brübach, Nils. 1994. Die Reichsmessen von Frankfurt am Main, Leipzig und Braunschweig. Stuttgart: Franz Steiner.

Buecher, Karl (ed.). 1915. Frankfurter Amts- und Zunfturkunden bis zum Jahre 1612.Frankfurt a. M.: Baer.

Capmany, and Antonio de Montpalau. 1779-92. Memorias historicas sobre la marina, comercio y Artes de la antigua ciudad de Barcelona. 4 volumes. Madrid.

Carande, Ramon. 1943. Carlos V y sus banqueros. 2 volumes. Madrid: Revista de Occidente.

Cleirac, Etienne. 1656/9. Usance du negoce ou commerce de la banque et des lettres de change. Paris.

Denzel, Markus A. 1994. La Practica della Cambiatura, Europäischer Zahlungsverkehr vom 14. bis zum 17. Jahrhundert. Stuttgart: Franz Steiner Verlag.

Denzel, Markus A. 2005. Die Bozener Messen und ihr Zahlungsverkehr. Bozen: Verlagsanstalt Athesia.

Denzel, Markus A. 2008. Das System des bargeldlosen Zahlungsverkehrs europäischer Prägung vom Mittelalter bis 1914. VSWG-Beihefte 201, Stuttgart: Franz Steiner Verlag.

Dickson, P. G. M. 1967. The Financial Revolution in England, A Study in the Development of Public Credit 1688-1756. London: MacMillan.

Dillen, Johnanes.G. van. 1934. The bank of Amsterdam. In History of the Principle 
Public Banks, ed. Johannes.G. van Dillen, 79-123. The Hague: Martinus Nijhoff.

Dillen, Johannes G. van. 1964. Oprichting en functie der Amsterdamse Wisselbank in de zeventiende eeuw 1609-1686; Bloeitijd der Amsterdamse Wisselbank 1687-1781; Ondergang van de Amsterdamse Wisselbank 1782-1820, In Mensen en achtergronden : studies uitg. ter gelegenheid van de 80. jaardag van de schrijver / J. G. van Dillen, ed. Johannes G. Dillen, 336-384 Groningen: Wolters.

E.B.A. 1773. Der in allen Fällen vorsichtige Banquier. Volume 2: Wechselordnungen. Leipzig.

Ehlers, Lars. 2002.”Coalitional Strategy Proof House Allocation.” Journal of Economic Theory, 105: 298-317.

Ehrenberg, Richard. 1896. Das Zeitalter der Fugger, Geldkapital und Creditverkehr im 16. Jahrhundert. Volume 2.Jena: Fischer.

Endemann, Wilhelm. 1885. Handbuch des deutschen Handels, See- und Wechselrechts. Volume 3. Leipzig: Fues.

Fabiano, L.1556/61. Trattato del cambio di Lione e di Bisenzone. Milano/ Perugia.

Face, R.D. 1957. Technique of Business in Trade between the Fiars of Champagne and the South of Europe in the 12th and 13th Centuries. Economic History Review, Second Series 10: 427-38.

Fuchs, Rudolf. 1955. Der Bancho Publico zu Nürnberg, Berlin: Duncker \& Humblot.

Franck, J.C. 1751. Institutiones iuris cambialis. Leipzig.

Gascon, Richard. 1971. Grand commerce et vie urbaine au XVIe siècle, Lyon et ses marchands. vol.1. Paris: S.E.V.P.E.N.

Gelderblom, Oscar and Joost Jonker. 2005. Amsterdam as the Cradle of Modern Futures and Options Trading 1550-1650. In The Origins of Value, The Fianncial Innovations that Created Modern Capital Markets, ed. William N. Goetzmann and K. Geert Rouwenhorst, 641-72. Oxford: Oxford University Press.

Goldschmidt, Levin. 1891. Handbuch des Handelsrechts. Volume 1. Stuttgart. 
Greif, Avner. 1993. "Contract Enforceability and Economic Institutions in Early Trade: The Maghribi Traders Coalition.” American Economic Review 83 (3): 525-548.

Greif, Avner. 2002. "Institutions and Impersonal Exchange, From Communal to Individual Responsibility.” Journal of Institutional and Theoretical

Economics 158 (1): 168-204.

Greif, Avner. 2006.Institutions and the Path to the Modern Economy, Lessons from Medieval Trade, Cambridge: University Press.

Greif, Avner, Paul Milgrom and Barry R. Weingast. 1994. "Coordination, Commitment, and Enforcement: The Case of the Merchant Guild.” Journal of

Political Economy 102 (4): 745-776.

Hasse, Ernst. 1885. Geschichte der Leipziger Messe. Leipzig: Hirzel.

Haristoy, J. 1906. Virement en banque et chambres de compensation. Paris: Arthur Rousseau.

Koenigk, Johann Christian. 1717. Der Berühmten Kauff- und Handelsstadt Leipzig Wechselordnung (von 1682) mit nützlichen Anmerkungen. Leipzig.

Hoffmann. 1910. Die Rechtsnatur der Abrechnungsstellen im Skontrationsverfahren. Dissertation Göttingen.

Koch, R. 1883. "Abrechnungsstellen (Clearinghäuser) in Deutschland und deren Vorgänger." Zeitschrift für das gesamte Handelsrecht 29: 59ff.

Lane, Frederic C., and Reinhold.C. Mueller, 1985. Money and Banking in Medieval and Renaissance Venice. Volume 1, Baltimore: Johns Hopkins University Press.

Lattes, Elia, 1869. La Libertà delle Banche a Venezia dal Secolo XIII al XVII. Milano: Valentiner e Mues Libraj-Editori.

Lopez, Robert, S. 1976. The Commercial Revolution of the Middle Ages, 950-1350. Cambridge: University Press.

Marperger, P.J. 1709. Neueröffnetes Handelsgericht. Hamburg.

Marperger, P.J. 1717. Beschreybung der Banken. Halle. 
Martens, G.F. von. 1794. Versuch einer historischen Entwicklung des wahren Ursprungs des Wechselrechts. Göttingen.

Merenda, Antonius. 1645. De Cambiis Nundinali. Papua.

Martin, Ruiz F. 1965. Lettres marchandes echangees entre Florence et Medina del Campo. Paris: S.V.P.E.N.

Miskimin, Harry. 1984. Money and Power in the Fifteenth Century France. New Haven: Yale University Press.

Munro, John. 1994. 'The International Law Merchant and the Evolution of Negotiable Credit in Late-Medieval England and the Low Countries." In: Textiles, Towns, and Trade: Essays in the Economic History of Late Medieval England and the Low Countries, ed. John Munro, 49-80. Ashgate: Aldershot.

Neuhaus. 1892. Die Skontration, ihre historische Entwicklung, juristische Natur und volkswirtschaftliche Bedeutung. Dissertation Erlangen.

North, Douglass C. 1981. Structure and Change in Economic History. New York: Norton.

North, Michael. 1996. Von Warenmessen zu den Wechselmessen, Grundlagen des Europäischen Zahlungsverkehrs in Spätmittelalter und Früher Neuzeit, In Europäische Messen und Märktesysteme in Mittelalter und Neuzeit, ed. Peter Johannek und Heinz Stoob, 223-238 Köln: Böhlau.

Opitz, Peter. 1968. Der Funktionswandel des Wechselindossementes. Berlin: Duncker \& Humblot.

Orth, J. P. 1765.Ausführliche Abhandlung von den berümten zwoen Reichsmessen so in der Reichsstadt Frankfurt am Main jährliche gehalten werden. Frankfurt am Main.

Parker, G. 1974. The Emergence of Modern Finance in Europe 1500-1730, In The Fontana Economic History of Europe, Volume 2 Chapter 7, ed C. Cipolla, Glasgow: Collins.

Peri, Giovanni D. 1638. Il Negotiante.

Pezzolo, Luciano and Giuseppe Tattara. 2008. "Una fiera senza luogo?: Was Bisen- 
zone an International Capital Market in Sixteenth-Century Italy." The Journal of Economic History 68(04): 1098-1122.

Phoonsen, Johannes. 1676. Wissel-Styl tot Amsterdam. Amsterdam.

Prausnitz, Otto. 1928. Die Forderungsverrechnung in geschichtlicher Entwicklung. Breslau: Wurst.

Quinn, Stephen and William Roberds.2006. "An Economic Explanation of Early Bank of Amsterdam, Debasement, Bills of Exchange, and the Emergence of the First Central Bank, Federal Reserve Bank of Atlanta Working Paper 2006-13.

Quinn, Stephen and William Roberds. 2007. "The Bank of Amsterdam and the Leap to Central Bank Money." American Economic Review 97(2): 262-265.

Raumburger. 1723. Justitia selecta gentium europaearum in cambiiis, Frankfurt.

Rodriguez and Fernández. 1903-1904. Historia de la muy noble, muy leal y coronada villa de Medina del Campo conforme á varios doc. y notas á ella perinentes. Madrid : S. Francisco de Sales.

Riccius, C. G.1782. Exercitationes in universum ius cambiale directae. Göttingen.

Roover, de Raymond. 1953. L'evolution de la lettre de change, Paris.

Roth, Alvin E., Tayfun Sönmez, and M. Utku Ünver. 2004. Kidney Exchange, in: Quarterly Journal of Economics 119: 457-488.

Roth, Alvin E., Tayfun Sönmez, and M. Utku Ünver. 2005. Pairwise Kidney Exchange, in: Journal of Economic Theory 125: 151-188.

Rubys, Claude de. 1604. Histoire véritable de la ville de Lyon. Lyon.

Savonne, Pierre de. 1567. Brieve instruction de tenir livres de raison ou de compte. Lyon.

Scaccia, S. 1648.Tractatus de commerciis et cambio. Frankfurt am Main.

Schaps, Georg. 1892. Zur Geschichte des Wechselindossaments. Stuttgart: Ferdinand Enke, Stuttgart.

Schneider, Jürgen. 1989. Hat das Indossament zum Niedergang der Wechselmessen 
beigetragen? In Geldumlauf, Währungssysteme und Zahlungsverkehr in Nordwesteuropa 1300-1800, Beiträge zur Geschichte der späten Hansezeit ed. Michael North, 183-195.Köln: Böhlau.

Schneider, Jürgen. 1991. Messen und Internationaler Zahlungsverkehr (Mittelalter bis 16. Jahrhundert), In Banchi pubblici, banchi privati e monti di pietà nell'Europa preindustriale: amministrazione, tecniche operative e ruoli economici, 133-169.Genoa: Società ligure di storia patria

Seyd, E. 1872. The London banking and bankers Clearinghouse-System, London.

Silva, Jose-Gentil da. 1969. Banque et Crédit en Italie au XVII Siecle. 2 Volumes. Paris: Editions Klincksieck.

Shapley, L. and H. Scarf. 1974. "On Cores and Indivisability." Journal of Mathematical Economics 1: 23-37.

Sneller, Zeger W. 1940. Rotterdams bedrijfsleven in het verleden. Amsterdam: H. J. Paris.

Sotus D. 1582. De iustitia det iure. Lyon.

Spufford, Peter. 1988. Money and its Use in Medieval Europe. Cambridge: Cambridge University Press.

Trenchant, J. 1556. L'arithméthique des marchands. Lyon.

Turri, Raphael de. 1645. Tractatus selecta gentium europaearum in cambiis. Frankfurt a. M.

Usher, Abbott P. 1943. The Early History of Deposit Banking in Mediterranean Europe. Cambridge MA: Harvard University Press.

Vasquez de Prada, Valentin. 1991. Die kastilischen Messen im 16. Jahrhundert, in: Rainer Koch (ed.), Brücke zwischen den Völkern - zur Geschichte der Frankfurter Messe, volume 1, Frankfurt a. M.: Historisches Museum.

Velde, Francois R. 2009. "The Case of the Missing Public Bank: Early Modern France." Preliminary Draft presented at the XVth World Economic History Congress, 
Utrecht.

Velden, H. van. 1933. "Het kassiersbedrijf te Amsterdam in de 17e eeuw." De Economist 82(1): 48-68.

Verlinden, Carles. 1971. Markets and Fairs, in: The Cambridge Economic History of Europe Vol. 3, Cambridge: Cambridge University Press, pp. 119-56.

Vigne, Marcelin. 1903. La banque a Lyon du XVe au XVIIIe siècle. Lyon: A. Rey.

Vries, Jan de and Ad van der Woude. 1997. The first Modern Economy: Success, Failure, and Perseverance, of the Dutch Economy, 1500-1815. Cambdridge: University Press.

Wee, Hermann van der. 1963. The Growth of the Antwerp Market and the European Economy. Den Haag: Martinus Nijhoff.

Wee, Hermann van der. 1977. Monetary, Credit and Banking Systems in: E.F. Rich and C.H. Wilson (eds.), The Cambridge Economic History of Europe, Volume 5, Cambridge: University Press, pp. 290-393.

Wee, Hermann van der. 1993.The Low Countries in the Early Modern World. Cambridge: University Press.

Wilson, Charles. 1941. Anglo-Dutch Commerce \& Finance in the Eighteenth Century. Camdridge: Univesrity Press 1941.

Wolf, Armin. 1967. Die Gesetze der Stadt Frankfurt am Main im Mittelalter. Frankfurt a. M.: Kramer.

Zipfel, H. 1701.Tractat von Wechselbrieffen und deren Usancen. Frankfurt a.M..

\section{Appendix}

\subsection{Proposition 1}

Suppose not. Then after all cycles have been removed, there exists some agent $i_{1}$ who has both debts and credits. Hence, for at least one individual $i_{2}$, we have that

$$
d_{i_{1}, i_{2}}>0
$$


Since this is true for every agent $i$, for any agent $i_{a}$ with $d_{i_{a-1}, i_{a}}>0$, there exists an agent $i_{a+1}$ such that $d_{i_{a}, i_{a+1}}>0$, as $i_{a}$ holds a balanced position. Hence, we can construct an ordered list of agents $i_{1}, i_{2}, \ldots, i_{N}, i_{N+1}$ for whom $d_{i_{a}, i_{a+1}}>0$. Since there are $N+1$ agents in this list, there must be an $a$ and $b$ such that $1 \leq a<b \leq i_{N+1}$ such that $i_{a}=i_{b}$. Hence, there still exists a cycle $i_{a}, i_{a+1}, \ldots, i_{b-1}, i_{a}=i_{b}$, which contradicts the assumption that all cycles have been removed.

\subsection{Proposition 2}

If all other agents truthfully reveal, it follows from Proposition 1 that agent $i$ will clear all his debts by truthfully revealing. Since this is the best agent $i$ can hope to do under any allocation, this is a best response.

\subsection{Proposition 3}

Assume that all chains are removed and the outcome is not efficient. Then there exists an agent $i$ whose has both a debt with some agent $j$ and is owed a debt by some agent $h$. Hence, $h, i, j$ constitutes a chain and not all chains have been removed, a contradiction.

\subsection{Proposition 4}

Let $\mathcal{A}^{\prime}$ be the allocation given a truthful revelation by agent $i$ and some revelation by other agents. Then a chain removal mechanism is strategy-proof if $i$ does not want to deny his debt with any $j$ such that $d_{i, j}^{\prime}>0$. Letting $\hat{d}_{i, j}^{\prime}$ denote the announcement by $i$, we have that $i$ 's ending utility will be

$$
-\left|\sum_{j=1}^{N} \hat{d}_{i, j}^{\prime}\right|-\sum_{j=1}^{N} d_{i, j}^{\prime}
$$

which is clearly less than or equal to

$$
-\left|\sum_{j=1}^{N} d_{i, j}^{\prime}\right|
$$

as $d_{i, j}>0$ (as the agent can only deny debts). For the last statement, note from the previous theorem that all agents when all agents report truthfully, all agents are reduced to their net 
positions. Since the disutility from any debtor is the same as from any other debtor, this implies that the allocation is Pareto efficient. 


\section{Diskussionsbeiträge des Fachbereichs Wirtschaftswissenschaft der Freien Universität Berlin}

2010

2010/1 BÖNKE, Timm / Sebastian EICHFELDER

Horizontal equity in the German tax-benefit system

Economics

2010/2 BECKER, Sascha / Dieter NAUTZ

Inflation, Price Dispersion and Market Integration through the Lens of a Monetary

Search Model

Economics

2010/3 CORNEO, Giacomo / Matthias KEESE / Carsten SCHRÖDER

The Effect of Saving Subsidies on Household Saving

Economics

2010/4 BÖNKE, Timm / Carsten SCHRÖDER / Clive WERDT

Compiling a Harmonized Database from Germany's 1978 to 2003

Sample Surveys of Income and Expenditure

Economics

2010/5 CORNEO, Giacomo

Nationalism, Cognitive Ability, and Interpersonal Relations

Economics

2010/6 TERVALA, Juha / Philipp ENGLER

Beggar-Thyself or Beggar-Thy-Neighbour? The Welfare Effects of Monetary Policy Economics

2010/7 ABBASSI, Puriya / Dieter NAUTZ

Monetary Transmission Right from the Start: The (Dis)Connection Between the Money Market and the ECB's Main Refinancing Rates

Economics

2010/8 GEYER, Johannes / Viktor STEINER

Public pensions, changing employment patterns, and the impact of pension reforms across birth cohorts

Economics

2010/9 STEINER, Viktor

Konsolidierung der Staatsfinanzen

Economics

2010/10 SELL, Sandra / Kerstin LOPATTA / Jochen HUNDSDOERFER

Der Einfluss der Besteuerung auf die Rechtsformwahl

FACTS

2010/11 MÜLLER, Kai-Uwe / Viktor STEINER

Labor Market and Income Effects of a Legal Minimum Wage in Germany

Economics

2010/12 HUNDSDOERFER, Jochen / Christian SIELAFF / Kay BLAUFUS / Dirk

KIESEWETTER / Joachim WEIMANN

The Name Game for Contributions - Influence of Labeling and Earmarking on the

Perceived Tax Burden

FACTS 
2010/13 MUCHLINSKI, Elke

Wie zweckmäßig ist das Vorbild der Physik für ökonomische Begriffe und Metaphern Economics

2010/14 MUCHLINSKI, Elke

Metaphern, Begriffe und Bedeutungen - das Beispiel internationale monetäre

Institutionen

Economics

2010/15 DITTRICH, Marcus und Andreas Knabe

Wage and Employment Effects of Non-binding Minimum Wages

Economics

2010/16 MEIER, Matthias und Ingo Weller

Wissensmanagement und unternehmensinterner Wissenstransfer

Management

2010/17 NAUTZ, Dieter und Ulrike Rondorf

The (In)stability of Money Demand in the Euro Area: Lessons from a Cross-Country

Analysis

Economics

2010/18 BARTELS, Charlotte / Timm Bönke

German male income volatility 1984 to 2008: Trends in permanent and transitory

income components and the role of the welfare state

Economics

2010/19 STEINER, Viktor / Florian Wakolbinger

Wage subsidies, work incentives, and the reform of the Austrian welfare system Economics

2010/20 CORNEO, Giacomo

Stakeholding as a New Development Strategy for Saudi Arabia

Economics

2010/21 UNGRUHE, Markus / Henning KREIS / Michael KLEINALTENKAMP

Transaction Cost Theory Refined - Theoretical and Empirical Evidence from a

Business-to-Business Marketing Perspective

Marketing

2010/22 POWALLA, Christian / Rudi K. F. BRESSER

Performance Forecasts in Uncertain Environments: Examining the Predictive Power of the VRIO-Framework

Strategic Management

2010/23 KREMER, Stephanie

Herding of Institutional Traders: New Evidence from Daily Data

Economics

2010/24 ROSTAM-AFSCHAR, Davud

Entry Regulation and Entrepreneurship

Economics

2010/25 DECKER, Carolin / Rudi K. F. BRESSER / Thomas MELLEWIGT

Strategic Or Status Quo-Preserving Business Exit: (How) Do CEO Turnover and

Succession Mattter?

Strategic Management

2010/26 NAUTZ, Dieter / Jan SCHEITHAUER

Monetary Policy Implementation and Overnight Rate Persistence

Economics 
The Economics of Debt Clearing Mechanisms

Economics 